\title{
Contradictions of the Labour Process, Worker Empowerment and Capitalist Inefficiency
}

\author{
Matt Vidal \\ Loughborough University London \\ m.vidal@lboro.ac.uk
}

\begin{abstract}
I articulate a classical-Marxist theory of technical change in the capitalist labour process, highlighting two contradictions. The management contradiction is the conflict managers experience between coordination (to increase efficiency) and discipline (to ensure valorisation). The workforce contradiction is the tension workers experience between productive socialisation and alienation. I submit that both contradictions were substantially muted from the earliest stages of capitalism through the Fordist stage but have become intensified in the postfordist period. Under postfordism, the basis of efficiency is economies of scope and flexibility, and thus there is a real efficiency advantage to empowering workers, via both multiskilling and employee involvement in problem-solving and decision-making. Postfordist capitalism has thus initiated an intensification of the management and workforce contradictions. In response, capitalist management is increasingly impeding the growth of the productive forces by failing to empower workers.
\end{abstract}

\section{Keywords}

contradiction - employee involvement - empowerment - deskilling - labour process Marxism - multiskilling - postfordism - Taylorism - technical change - upskilling

For Marx, the defining features of the capitalist labour process are production of commodities (goods and services) for profit, cooperation within a division of labour under managerial authority, and conflict over autonomy, effort and output. ${ }^{1}$ The most fundamental imperative is the securing of surplus labour:

1 Marx 1990.

(C) MATT VIDAL, 2019 | DOI:10.1163/1569206X-00001792

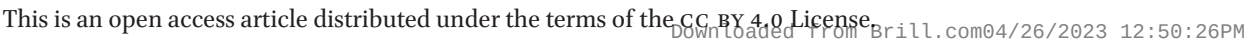


labour performed beyond that required to reproduce the worker according to a historically determined standard of living. Marx referred to the production of surplus labour as the valorisation process.

Following the influential contribution of Braverman, Marx's theory of the labour process has been widely understood to propose that deskilling is inherent to capitalist management, accomplished via work simplification and mechanisation. ${ }^{2}$ Subsequent labour-process theory has documented and theorised a range of control strategies, from responsible autonomy to bureaucratic control, hegemonic control, normative control and beyond. A controlresistance framework emerged that informed empirical research across a wide range of industrial, occupational and institutional contexts. Labour-process theory has produced a rich body of empirical work and numerous theoretical insights on the problem of managerial control, the role of agency and institutions in shaping work regimes, and the impact of broader political-economic pressures and trends, including intensified international competition, financialisation and liberalisation. ${ }^{3}$ Across the oECD, postfordist capitalism has been characterised by a decline of internal labour markets, a rise in low-wage, dead-end jobs, and increased work intensification across sectors and occupations. In the US around $28 \%$ of all jobs are low-skill, unrationalised labourintensive, with an additional $7 \%$ being highly standardised and low-autonomy. ${ }^{4}$

Yet, despite the structural problem of bad jobs and the persistence of (neo) Taylorism, qualitative and quantitative evidence has documented real, if limited, movements toward cross-training and employee involvement in postfordist manufacturing and service contexts. ${ }^{5}$ Labour-process theory has not developed a coherent theoretical analysis of such contradictory trends. Marx's argument that capitalism is a dynamic system that continuously transforms the labour process and the functions of the worker within it has not been widely appreciated. Observations of job rotation among simple tasks are said to demonstrate a lack of genuine multiskilling and the persistence of deskilling as a capitalist imperative. ${ }^{6}$ Employee-involvement programmes have been widely

2 Braverman 1974.

3 For overviews, see Smith 2015; Thompson and Smith 2009; Thompson and van den Broek 2010; Vidal and Hauptmeier 2014.

4 Vidal 2012; Vidal 2013a.

5 For evidence, see Adler 1993; Adler 2007; Albizu and Olazaran 2006; Delbridge 2003; Elger and Smith 2005; Jürgens 2004; Leverment, Ackers and Preston 1998; Lowe, Delbridge and Oliver 1997; Oliver and Wilkinson 1992; Rothstein 2016; Stanton, Gough, Ballardie, Bartram, Bamber and Sohal 2014; Vidal 2007b; Vidal 2017.

6 For example, Rinehart, Huxley and Robertson 1997; Stewart, Richardson, Danford, Murphy, Richardson and Wass 2009 . 
dismissed as superficial responses to labour unrest. ${ }^{7}$ It is a minority view to see worker participation as a real technical advance in the labour process, which remains limited due to managerial attempts to maintain control. ${ }^{8}$

In this paper I work in the latter vein, developing a theory and research programme for explaining and examining upskilling and worker empowerment as substantive, but systematically limited technical developments within the postfordist labour process. I begin by presenting a classical interpretation of Marx focused on capitalist development as a contradictory process unfolding across stages. From there, I discuss contemporary theory in three steps: Fordism and postfordism as the growth stages following those identified by Marx; theories of the capitalist production of inefficiency; and contradiction and employee involvement within labour-process theory. Finally, I articulate a theory of technical change within the labour process that emphasises two central contradictions - the management contradiction and the workforce contradiction - and how these have become intensified in the postfordist stage of capitalism, leading to an increasing fettering of technical growth under capitalist management.

\section{Revisiting Marx: Contradictions, the Labour Process and Stages of Growth}

This section presents a classical interpretation of Marx on the labour process, focusing first on management and then on labour.

\section{Management: Coordination and Discipline ${ }^{9}$}

The concept of material contradiction was central to Marx's historical materialism. A material contradiction exists where a social process consists of two interdependent processes that are potentially in conflict. ${ }^{10}$ For Marx, one of the most fundamental contradictions of human society is that between the forces and relations of production. ${ }^{11}$ The forces and relations of production are deeply interdependent elements of the process of human production, at times mutually reinforcing, at times conflicting. Because humans are inherently creative animals who consciously engage in production to realise

$7 \quad$ Aglietta 200o; Braverman 1974; Edwards 1979; Friedman 1977; Stewart, Richardson, Danford, Murphy, Richardson and Wass 2009.

$8 \quad$ Adler 2007; Cressey and MacInnes 1980; Elger 1979; Littler 1982; Thompson 1983.

9 This section covers material also discussed in Vidal 2019 .

10 Callinicos 2009.

11 Marx and Engels 1978. 
preconceived goals, there is an autonomous tendency for the productive forces of society to develop. Existing relations of production at first facilitate the growth of productive capability, but, as technology continues to develop, the relations of production eventually begin to retard technological development.

Within the workplace, the contradiction between the forces and relations of production operates via conflicting pressures associated with the labour process and the valorisation process. As human techniques for producing usevalues, labour processes are part and parcel of the forces of production. As power relations for extracting surplus-value from labour, specific to capitalism, valorisation processes are part of the relations of production. The process of capitalist production is thus inherently contradictory, being 'on the one hand a social labour process for the creation of a product, and on the other hand capital's process of valorisation.' ${ }^{2}$

Marx clearly and consistently argued that managerial hierarchy and the detail division of labour in the factory were historically necessary for technical growth, but there has been much confusion on this point. Marglin famously argued that neither were ever technically necessary. Authority hierarchies are the result of capitalists inserting themselves into the labour process in order to extract income, 'at the expense of workers', without increasing the efficiency of production. Marglin implied his thesis was Marxist, suggesting Engels had got it wrong: 'Perhaps it was a momentary aberration, but at one point in his career at least, Engels saw authority as technologically rather than socially determined. ${ }^{13}$

Braverman criticised the same article of Engels' for failing to distinguish forms of authority. ${ }^{14}$ While Braverman accepted that breaking tasks into their basic elements does increase organisational efficiency, along with Marglin he proposed that the Babbage principle - breaking tasks down so that the simplest tasks can be performed by unskilled workers - is about profit, not efficiency as such.

Marx's position on managerial authority and the division of labour must be understood within his stage-theory of capitalist development, which distinguished three stages: cooperation, manufacture, and large-scale industry. ${ }^{15}$ Cooperation refers to the initial process by which capitalists gathered workers together into a single location under the authority of a single capitalist. This stage unfolded over the fifteenth and sixteenth centuries.

\footnotetext{
12 Marx 1990, p. 45o.

13 Engels 1978; Marglin 1974, p. 62.

14 Braverman 1974, pp. 11-12, footnote.

15 Marx 1990.
} 
For Marx, capitalists were necessary for cooperation in commodity production: 'concentration of large masses of the means of production in the hands of the individual capitalists is a material condition for the cooperation of wagelabourers, and the extent of cooperation, or the scale of production, depends on this extent of concentration. ${ }^{16}$ In addition to the need for financial capital, the commanding authority of the capitalist was also technically necessary: 'Through the co-operation of numerous wage-labourers, the command of capital develops into a requirement for carrying on the labour-process itself, into a real condition of production. That a capitalist should command on the field of production, is now as indispensable as that a general should command on the field of battle.'

The stage following cooperation was manufacture, under which capitalists introduced the detail division of labour. Even though Marx saw deskilling as the dominant tendency within this and the subsequent stage of capitalist development, he did not articulate a thesis of universal deskilling like Braverman did. For Marx, the complex functions of skilled labour can be simplified but not eliminated. Thus, there remains 'a hierarchy of labour-powers, to which there corresponds a scale of wages.... Alongside of the gradations of the hierarchy, there appears the simple separation of the workers into skilled and unskilled.'17 This stage lasted from the sixteenth through the eighteenth century.

Marx was clear that the use of detail workers was efficiency-increasing: 'The worker's continued repetition of the same narrowly defined act and the concentration of his attention on it teach him by experience how to attain the desired effect with the minimum of exertion ... in comparison with the independent handicraft, more is produced in less time, or in other words the productivity of labour is increased.'18

Responding to Marglin, Landes, a mainstream economic historian, articulated a point more consistent with Marx's own position: increasing profit by decreasing prices was the motive behind centralisation of production and economies of scale. ${ }^{19}$ The typical craft worker simply did not have these goals in mind, and where they did, they became a protocapitalist by subcontracting work to others. In short, the profit motive, a peculiarly capitalist logic, was necessary for transforming craft production into large-scale industry to realise economies of scale.

\footnotetext{
16 Marx 1990, p. 448.

17 Marx 199o, pp. 469-70.

18 Marx 1990, p. $45^{8}$.

19 Landes 1986.
} 
The next stage was large-scale industry, distinguished by the use of machinery (rather than hand tools) and occurring during Marx's lifetime. He explained how machinery allows the employment of women and children in the factory, provides incentives to extend the working day in accordance with the potential of the machine, is a highly effective means of controlling and intensifying labour, and increases the surplus-labour population, which further disciplines labour.

However, in line with his theory of technical change as a contradictory process, Marx envisioned a progressive tendency conflicting with the regressive tendency of deskilling and retarded by capitalist relations of production:

Large-scale industry, by its very nature, necessitates variation of labour, fluidity of functions, and mobility of the worker in all directions. But on the other hand, in its capitalist form it reproduces the old division of labour with its ossified particularities. We have seen how this absolute contradiction does away with all repose, all fixity and all security as far as the worker's life-situation is concerned ... in the ceaseless human sacrifices required from the working class.... This is the negative side. But ... large-scale industry, through its very catastrophes, makes the recognition of variation of labour and hence of the fitness of the worker for the maximum number of different kinds of labour into a question of life and death. This possibility of varying labour must become a general law of social production, and the existing relations must be adapted to permit its realisation in practice. That monstrosity, the disposable working population held in reserve, in misery, for the changing requirements of capitalist exploitation, must be replaced by the individual man who is absolutely available for the different kinds of labour required of him; the partially developed individual, who is merely the bearer of one specialized social function, must be replaced by the totally developed individual, for whom the different social functions are different modes of activity he takes up in turn. ${ }^{20}$

To be sure, the detail division of labour and mechanisation under capitalist competition degrade labour and generate a reserve army of surplus labour. Furthermore, Marx was not arguing that a fully developed individual would be produced within capitalism. Rather, I interpret this passage to mean Marx was theorising a developmental tendency within large-scale industry - and within the dynamic of ever-increasing technical change - toward the multiskilling of labour, although such a trend would be retarded by capitalist management. 
Such a development should be understood within the context of Marx's argument that 'higher relations of production never appear before the material conditions of their existence have matured in the womb of the old society itself. ${ }^{21}$ As the contradictory process of technical change continued apace, there would be increased conflict between a tendency toward deskilling and an increasing technical need for multiskilled workers.

Critically, the nature of managerial authority is twofold. On the one hand, management plays a productive role: "The work of directing, superintending and adjusting becomes one of the functions of capital, from the moment that the labour under capital's control becomes co-operative."22 'This is productive labour that has to be performed in any combined mode of production. ${ }^{23} \mathrm{On}$ the other hand, management plays an unproductive role: 'The control exercised by the capitalist is not only a special function arising from the nature of the social labour process, but it is, at the same time, a function of the exploitation of a social labour process, and is consequently conditioned by the unavoidable antagonism between the exploiter and the raw material of his exploitation.'24

Marx suggested that the content of management is both productive and unproductive, while the form is always despotic. Without getting bogged down by the Hegelian distinction between form and content, Marx's discussion of the dual roles of management can be articulated via a distinction between coordinating ('directing, superintending and adjusting') the division of labour to increase efficiency and disciplining labour to ensure the extraction of sufficient output. While Marx saw the dual functions of management as 'inseparably fused', analytically they stem from distinct (though interrelated) sources: coordination is part and parcel of the productive forces while discipline flows from antagonistic production relations. ${ }^{25}$

\section{Labour: Socialisation and Alienation}

Received wisdom holds that Marx argued capitalism necessarily leads to the absolute immiseration of the working class and the homogenisation of working conditions. While Marx did articulate such a thesis in the Manifesto, this 'youthful writing' was written 'before he had brought his theoretical understanding of the capitalist mode of production to its final, mature conclusion. ${ }^{26}$

\footnotetext{
$21 \quad$ Marx 1978b, p. 5 .

22 Marx 1990, p. 449.

23 Marx 1981, p. 507.

24 Marx 1990, p. 449.

25 Marx 1981, p. 510.

26 Mandel 1990, p. 70.
} 
Beginning with the Grundrisse and through Capital, there is 'no longer a trace of any such trend towards absolute impoverishment in his economic analysis'. The wage theory in Capital holds that wages are determined by the costs of reproducing labour (which differs for distinct skill levels), including both physiological needs and what a given society considers an acceptable standard of living based on its wealth and productivity. ${ }^{27}$ It predicts real wages will be higher in more advanced countries and will increase in more advanced stages of capitalism.

Marx did of course vehemently denounce the denial of the needs of workers as humans, in terms of skill development and opportunities for intellectual engagement in their work, under the detail division of labour. The latter 'converts the worker into a crippled monstrosity by furthering his particular skill as in a forcing-house, through the suppression of a whole world of productive drives and inclinations.' Rather than suggesting immiseration in the form of material impoverishment, Marx's critique of the capitalist labour process emphasised alienation and physical degradation under extreme task specialisation and unchecked managerial despotism, which would occur be his payment high or low'.28 As is well known, Marx discussed four ways in which labour becomes alienated under capitalism: from the product, the process, fellow workers, and one's essential being as a conscious controller of one's own creative labour. ${ }^{29}$

It is critical to understand Marx's argument as a dynamic theory of history consisting of contradictory forces that develop and mature over distinct stages. In the Manifesto, Marx and Engels wrote eloquently on how the world market brings humanity together, having given

immense development to commerce, to navigation, to communication by land.... The bourgeoisie has through its exploitation of the worldmarket given a cosmopolitan character to production and consumption in every country.... National one-sidedness and narrow-mindedness become more and more impossible.... The bourgeoisie, by the rapid improvement of all instruments of production, by the immensely facilitated means of communication, draws all, even the most barbarian, nations into civilisation.... It has created enormous cities ... and has thus rescued a considerable part of the population from the idiocy of rural life. ${ }^{30}$

\footnotetext{
27 Marx 1990, Chapter 6.

28 Marx 1990, pp. 481, 788.

29 Marx 1978a, pp. 70-81.

$30 \quad$ Marx and Engels 1978, pp. 575-7.
} 
Adler interprets this and other passages as indicating that alongside shorterterm processes of degradation and immiseration, Marx theorised a longerterm tendency toward a more progressive form of socialisation. ${ }^{31}$ This notion of socialisation (Vergesellschaftung) refers to the transformation of people and means of production from individual/private into collective/social. But in Marx's usage the concept - what we might call productive socialisation to distinguish it from the notion of socialisation as the learning of social norms, institutional logics and conceptual schemas - is expansive.

We can read Marx as theorising a process of upgrading the capabilities of humans and technology over time based on the progressive accumulation of scientific and technical knowledge. In the Grundrisse, Marx discussed how the universality of capitalist production and exchange 'produces not only the alienation of the individual from himself and from others, but also the universality and the comprehensiveness of his relations and capacities. ${ }^{32}$ In Capital, he wrote of how 'When the worker cooperates in a planned way with others, he strips off the fetters of his individuality, and develops the capabilities of his species.' And 'it is only socialised labour that is capable of applying the general products of human development, such as mathematics, to the immediate process of production. ${ }^{33}$ Consider the situation today, where many factory and retail workers work under a Taylorist division of labour while using computers.

Now, Marx often discussed 'socialised labour' in the form of the 'collective worker', referring to how the basic unit of production in capitalism is not the individual but the collective under an interdependent division of labour. And he did write that 'In manufacture, the social productive power of the collective worker, hence of capital, is enriched through the impoverishment of the worker in individual productive power. ${ }^{34}$ Yet, as we have seen above, his dynamic and nuanced analysis posited a developmental tendency toward the multiskilling of labour. Indeed, 'Modern industry never views or treats the existing form of a production process as the definitive one. Its technical basis is therefore revolutionary.... it is continually transforming not only the technical basis of production, but also in the functions of the worker and the social combinations of the labour process.' As technical growth, technical complexity and interdependence increase under the ever-changing division of labour, productive socialisation - both inside and outside the workplace - will generate

$31 \quad$ Adler 1990; Adler 2007.

$32 \quad$ Marx 1993, p. 162.

33 Marx 1990, pp. 447, 1024.

34 Marx 1990, pp. 483, 617. 
increasingly sophisticated workers, although this may be limited by contradictory tendencies.

Popular education is a fundamental force increasing the productive capacity and technical sophistication. ${ }^{35}$ Marx saw the Factory Acts, which included an education clause, as a 'necessary product of large-scale industry', the 'first conscious and methodical reaction of society against' the extreme degradation of labour produced by unregulated capitalism. The progressive side of the contradictory nature of technical change is further illustrated with respect to technical education:

One aspect of this process of transformation, which has developed spontaneously from the foundation provided by large-scale industry, is the establishment of technical and agricultural schools. Another is the foundation of 'écoles d'enseignement professionnel' [vocational schools] in which the children of the workers receive a certain amount of instruction in technology and in the practical handling of the various implements of labour.

Elementary education, and vocational and technical schools are integral elements of capitalist development, with the result that 'basic skills, knowledge of commerce and languages, etc., are reproduced ever more quickly, easily, generally and cheaply' ${ }^{36}$

In sum, Marx theorised a contradictory dynamic between alienation and deskilling, on the one hand, and the productive socialisation of labour via an increase in its organisational and technical capabilities, on the other. A longterm, progressive trend toward productive socialisation is inherent to capitalist development but distorted and retarded by short-term concerns with securing surplus-value.

\section{Regimes of Accumulation, Managerial Control, and Employee Involvement}

This section develops the classical-Marxist framework articulated above using the regulation theory of accumulation regimes, interrogates the thesis that capitalist management prioritises control over efficiency, and reviews responses to employee-involvement programmes within labour process theory.

35 Marx 1990, pp. 617-18, 613; emphasis added.

$36 \quad$ Marx 1981, pp. 414-15. 


\section{Fordism and Postfordism}

Marx's stage theory of development was extended by Aglietta and Palloix. ${ }^{37}$ Focusing on the USA, they added a fourth stage, Fordism, based in automation and standardised, semiskilled labour. Aglietta's book was the founding document of regulation theory, which holds that extended periods of growth are possible within crisis-prone capitalism only when certain institutional configurations are realised to stabilise the economy. Although some early critiques made important points, ${ }^{38}$ they did not make the case for a wholesale rejection of regulationist stage-theoretic analysis or of the concept of Fordism. I agree with Brenner and Glick that the standard regulationist growth model, based on a distinction between an economic regime of accumulation and an institutional mode of regulation, is fundamentally problematic. In my own work I have rejected this distinction, instead theorising accumulation regimes as socially constructed institutional settlements, which may or may not achieve institutional coherence or complementarity. ${ }^{39}$ And there has been a great deal of sound, comparative historical work fleshing out the theory of Fordism as a unique institutional settlement and conjuncture in Western capitalism. ${ }^{40}$

In response to the crisis of Fordism in the 1970s, it became fashionable to speculate about functional postfordist futures, with many assuming there would be a return to strong growth, based largely in a post-Taylorist utopia in which workers are unproblematically empowered, contradictions resolved and mutual gains realised. ${ }^{41}$ I agree with criticisms of these utopian visions, which are inconsistent with the diversity of employment arrangements in advanced capitalism, including declining employment security, increased work intensification and rising inequality. ${ }^{42}$ But, again, there has been much compelling and fruitful work theorising postfordism as an inherently dysfunctional accumulation regime characterised by stagnation, financialisation and regressive labour-market trends. ${ }^{43}$

Fordism was unusually and remarkably institutionally coherent. The core production model was mass production of standardised products using

37 Aglietta 20oo; Palloix 1976.

38 Brenner and Glick 1991; Clarke 1992; Williams, Haslam and Williams 1992.

39 Vidal 2012; Vidal 2013b; Vidal 2014; Vidal 2015; Vidal 2019b.

40 Albritton, Itoh, Westra and Zuega 2001; Boyer and Saillard 2002; Jessop 1992; Jessop 1997; Jessop 2002; Jessop 2012; Lipietz 1986; Marglin and Schor 2007; Ryner and Cafruny 2017; Vidal 2015; Vidal 2019b.

41 Boyer 1997; Lipietz 1992; Piore and Sabel 1984.

42 Thompson 2003.

43 Amin 1994; Belfrage 2017; Crowley, Tope, Chamberlain and Hodson 2010; Jessop 1992; Jessop 2014; Peck and Theodore 2007; Ryner and Cafruny 2017; Vidal 2012; Vidal 2013b. 
forecast-driven, batch production, Taylorist work organisation, and a mix of special- and general-purpose machines. The Fordist accumulation regime included domestic mass-production for domestic mass-markets, national union contracts with wages indexed to productivity, and the Bretton Woods monetary order, which allowed national policy autonomy for Keynesian welfare states.

The growth trajectory from Fordism to postfordism applies to Atlantic capitalism, having been broadly followed in North America and Western Europe. ${ }^{44}$ The Fordist period can be dated roughly from 1927 (when Ford adopted batch production) to 1973, when the Bretton Woods financial system collapsed, macro indices on profit rates, growth rates and productivity turned downward, and classical Fordist production was in crisis due to increased resistance on the shopfloor and competition from more flexible models in Germany, Sweden and Japan. The postfordist period can be dated roughly from the early 1980 os to the present, following a decade of industrial restructuring, including offshoring of manufacturing, financialisation, vertical disintegration and deunionisation.

The core postfordist production model is diversified mass production of standardised products and services, using demand-driven, flow production, neotaylorist work-organisation and flexible, computerised machines. The dominant production model of postfordism is lean production, but in practice there is a range of other production and employment-relations regimes. The postfordist accumulation regime is characterised by intense international competition, stagnant growth and rising inequality at the macro-level and, at the micro-level, by the contradictory and limited empowerment of some workers alongside qualitative work-intensification for most workers and rising precarity for many. I return to the postfordist labour process and lean production in detail below.

Like Braverman, Aglietta saw job enrichment and enlargement programmes as superficial forms of employee involvement that were driven exclusively by problems with labour control, in particular labour unrest, absenteeism and sabotage under increasing work intensification. In contrast - and consistent with the interpretation of Marx offered above - Gorz and Mallet saw employee-involvement programmes as substantive changes in the labour process driven by technical change. ${ }^{45}$ Automation and ever-increasing technical change were rendering-obsolete narrow specialisations. Technical complexity was increasing, thus raising the demand for highly skilled, technical workers. Workers' control of production via self-directed teams of polyvalent workers is now at the technological frontier, but the need for capitalists to maintain

44 Jessop 2002; Jessop 2012; Vidal 2015; Vidal 2019b.

45 Gorz 1968; Gorz 1976; Mallet 1975. 
control means that there will be a continuation of a detailed division of labour and managerial hierarchy.

Gorz and Mallet highlighted contradictory dynamics under automation and the increasing pace of technical change. For Gorz, there is a contradiction between the 'technical initiative' required of skilled workers and the 'passive, disciplined submission to the orders and standards handed down by management'.46 For Mallet, the contradiction is between 'integration into an interesting technical universe which man naturally aims to understand and dominate, and the structure of command ... the decisions which exclude almost all those who help in the functioning of this universe. ${ }^{47}$

\section{Control versus Efficiency?}

While French Marxists were grappling with transformations in Fordist production, American Marxists were focusing on how capitalists, their managers and engineers prioritise controlling labour over efficiency. Echoing Marglin and Braverman, Gordon suggested that managers design the production process to ensure the reproduction of class relations, not by reducing costs but by adopting practices that are 'better able to discipline their workers, avoid strikes, and extract surplus product from their labour'.48 In an otherwise deeply-insightful and richly-evidenced book, Richard Edwards posited a more restricted prioritisation of valorisation over efficiency, proposing that managerial hierarchy increases profits by increasing 'control over the labour process' even though 'this profitability does not in general result from greater efficiency' 49

Gordon and Edwards are correct to assert managers often fail to adopt practices that would increase efficiency, and that managers often seek to maintain control (in a broad sense), which sometimes leads to a failure to adopt practices that would increase efficiency. But both problematically pose a straightforward choice between valorisation or efficiency. In Edwards's terms, managers consider 'transforming labour power into labour' independently of 'possibilities for achieving efficiencies. ${ }^{50}$ This distinction is theoretically unsound.

First, transforming labour-power into labour is identical to labour productivity (i.e. output per labour-hour). It is thus necessarily an efficiency concern. Second, Edwards proposed a choice between two technologies: Technology A has a higher rate of labour productivity ('labour control'); Technology B has

\footnotetext{
$46 \quad$ Gorz 1968, p. 36.

$47 \quad$ Mallet 1975, p. 12.

48 Gordon 1976, pp. 22-3; emphasis added.

49 Edwards 1979, pp. viii, 112.

50 Edwards 1979, p. 112.
} 
a higher rate of overall efficiency. Technology A could produce higher labour productivity either via machinery or management technique. However, for Technology B to produce a higher rate of overall efficiency while having a lower rate of labour productivity, it would have to be a form of automation that replaces workers. According to both mainstream economic theory and Marx's value theory, a rational manager under competitive pressure will generally adopt Technology B, substituting capital for labour, even if (as in Marx's theory) it pushes the profit rate down. The Edwards scenario of managers sacrificing overall efficiency to ensure the extraction of surplus labour is implausible, being inconsistent with both mainstream theory and Marxist theory.

Gordon, Edwards and Reich presented examples of mechanisation replacing skilled workers, but they did not demonstrate that the adopted technologies were less efficient than those they replaced. ${ }^{51}$ Indeed, they admitted in a footnote that "it is difficult to disentangle the effects of "labour control" imperatives from more traditional cost-minimizing forces and to assess the relative importance of each.'

Noble advanced a broadly similar argument, making it the thesis of a masterful study, Forces of Production..$^{52}$ However, although his book is forcefully argued, rich with historical data and theoretical insight, the data do not support the strong version of his argument, namely, that a concern with control made engineers choose automation and deskilling over more efficient technologies that use skilled workers.

Noble never defined control but used the term much more broadly than Edwards, arguing that capitalists, their engineers and managers effectively all adhered to a 'worldview of total control', a central part of which was 'the dream of the automatic factory' and 'the postwar preoccupation with controlling labour as an end in itself ${ }^{\prime 3}$ He presented compelling evidence that a logic of standardisation and automation dominated the engineering profession, both within corporate America and among scientists in the university. However, Noble did not provide any evidence that the standardisation/automation logic was driven by class interests, as opposed to a general belief in the power of science and technology. Lacking evidence regarding the role of class interests, he theorised engineers as an ideologically homogenous group, indeed, as a largely passive category of automatons that - with a small number of exceptions that prove the rule - uniformly enact a clear vision of total capitalist control.

$5^{1} \quad$ Gordon, Edwards and Reich 1982, p. 113; emphasis added.

$52 \quad$ Noble 1986.

53 Noble 1986, pp. 83, 56, 57; emphasis added. 
In effect, Noble condemned engineers for having an engineering outlook and for not understanding the nature of power and class. This is a far cry from showing that strategic choice, driven by class interests, decisively shaped the development of technology in a way that ensured deskilling against a viable alternative. The data he presented can be interpreted more persuasively requiring fewer assumptions - to show the opposite: automation in machine tools was driven by structural forces leaving little scope for strategic choice; efficiency-driven attempts to develop standard parts and profit-driven attempts to secure mass consumer markets combined to ensure the dominance of the engineering logic of standardisation/automation. Together structural forces left very little room for technical choice.

Noble did uncover a handful of dissenters to the dominant logic of full automation in machine tools, advocating 'record-playback' programming by skilled machinists on the shopfloor. Referring to all of the dissenters by name, Noble argued that the possibly cheaper and simpler approaches to numerical control promoted by Caruthers, Cunningham, Thomas, and Parsons fell by the wayside. ${ }^{54}$ But these designs were either abandoned before working prototypes were completed or were not purchased because they were 'contrary to the predispositions of both managers and engineers in industry who were buying and installing new equipment.5 ${ }^{5}$ This does not demonstrate engineers and managers choosing control over efficiency. Rather, it shows the influence of the standardisation/automation logic: these engineers really believed full automation was more efficient. His data simply did not demonstrate that a preoccupation with labour control overwhelmed the concern of engineers with efficiency.

This is not to suggest it is uncommon for decisions inside the firm to prioritise some other goal over efficiency. As Thomas has persuasively shown, decisions on new technologies are often made according to goals defined by powerful groups inside the organisation rather than what is most efficient. ${ }^{56}$ But the trade-off here concerns efficiency versus other goals, rather than efficiency versus control. Against Noble's picture of a homogeneous engineering profession, Thomas's study emphasised how engineers inside firms develop distinct goals concerning their relative statuses, which affect the identification of problems and solutions.

Indeed, Thomas made a similar point to Noble, suggesting that the development of expertise in automation may make staff 'likely to become predisposed

54 Noble 1986, pp. 146, 90; emphasis added.

55 Noble 1986, p. 95.

56 Thomas 1994, pp. 12-13, 206. 
to automation of technical systems even when pursuit of further automation is not the optimal response'. However, Thomas also argued that despite the social shaping of technological adoption inside the firm, 'dramatic technological innovations can shock organisations (or entire industries) and force them to respond'. As I will discuss in more detail below, this is precisely what happened with the Toyota Production System (lean production), whose engineers realised that traditional Taylorist deskilling had hit a limit and that the input of shopfloor workers was increasingly necessary, thus initiating a global production model in which employee involvement is central in theory, albeit limited in practice.

In sum, Braverman and Noble posited that capitalists pursue the absolute deskilling of labour to protect their class-power, while Gordon and Edwards suggested that capitalists prioritise valorisation over efficiency. All of these authors were on to something, but each formulation is problematic. The argument I develop here is in the vein of Gorz and Mallet: as the technological frontier shifts from a detail division of labour using semiskilled workers to multiskilled, substantively empowered workers, there is an emergent, tendential threat to capitalist management. Below I theorise this in terms of satisficing managers settle for limited forms of worker empowerment that increase efficiency and maintain their power but are far less efficient than more substantive forms of worker empowerment which threaten their power. But first I briefly review labour-process theory proper.

\section{Empowerment and Contradiction in Labour-process Theory}

In response to Braverman, Friedman introduced the concept of responsible autonomy ('status, authority and responsibility') and Edwards the concept of bureaucratic control (impersonal regulations set out in company policy, with internal labour markets to induce loyalty) ${ }^{57}$ Both authors suggested that each strategy emerged as an attempt to resolve contradictions of the previous strategy of direct/personal control. And both suggested that employee-involvement programmes are reactive responses to labour-management conflict or concessions to organised labour, rather than being efficiency-enhancing practices as such. Burawoy theorised how the organisation of the labour process individualises the workforce and encourages game playing, increasing the commitment of workers to their work. However, he effectively theorised consent as the inevitable outcome of working within the monopoly-capitalist firm, thus 
missing the most interesting points about contradiction, management and resistance. .8

Another group of scholars highlighted the dynamic tension between deskilling and upskilling, a contradiction seen to be increasing in the age of flexibility. Elger, Cressey and MacInnes, Littler, and Thompson all saw job enrichment and worker participation as constituting a real technical advance in the labour process, one that is systematically limited due to the competing pressures facing management and to the latter's attempt to maintain their own authority. ${ }^{59}$ Paul Edwards theorised the relative autonomy of the labour process. ${ }^{60}$ Managers and workers must interpret and deal with the multiple pressures bearing on any workplace, including general contradictions but also a range of particular circumstances, meaning their interests are not given by their objective class-location but are developed based on multiple sources of identity.

Following this wave of fruitful theoretical development in the 1980s, the subsequent literature has been dominated by two schools: Bravermanians who see deskilling as the dominant trend, and Friedmanites/Edwardsians who catalogue a range of managerial control regimes. Writers in the Bravermanian vein continue to contend that worker participation is a rhetorical device that merely dresses up deskilling and work-intensification. ${ }^{61}$

In taking stock of the early debate, Thompson articulated what he called the 'core theory' of the labour process, which holds that the capital-labour relation is inherently antagonistic, although the labour process itself is relatively autonomous from and may operate independently of broader class relations. ${ }^{62}$ Managers have a control imperative but may adopt a range of strategies. Thompson's specification of the core theory was highly perceptive, providing a good indication of how labour-process research would develop in the subsequent years. The research programme focusing on forms of control, resistance and accommodation has produced a rich body of empirical studies uncovering complexity and contingency.

However, contemporary labour-process theory has largely been divorced from the classically Marxist question of the contradictory nature of technological change. A small number of contributions have made conflicting pressures and dynamic tensions in labour management a systematic focus of their

\footnotetext{
58 Thompson 1983; Vallas 1993.

59 Cressey and MacInnes 1980; Elger 1979; Littler 1982; Thompson 1983.

6o Edwards 1979, pp. 55, 76 .

61 Carter, Danford, Howcroft, Richardson, Smith and Taylor 2013; Danford 1999; Stewart, Richardson, Danford, Murphy, Richardson and Wass 2009.

62 Thompson 1990.
} 
analysis, but, with the exception of Chris Smith, these have been empirical observations that have not been theorised using Marxism. ${ }^{63}$ One common theme has been conflicting pressures on managers for standardisation versus flexibility in both manufacturing and interactive services. ${ }^{64}$ Another theme, echoing Friedman, highlights the tensions facing workers between participating in employee-involvement programmes while experiencing work intensification. ${ }^{65}$ Relatedly, Thompson suggested a contradiction 'between what capital is seeking from employees in the labour process and what it finds necessary to enforce in the realm of employment relations', most notably decreased employment security. ${ }^{6}$

\section{The Management Contradiction, the Workforce Contradiction, and the Fettering of Technical Growth by Capitalist Management}

I now turn to elaborate my own argument, which is that two contradictions are intensifying in the postfordist era. In response to these intensified contradictions, capitalist management is systematically generating inefficiency and increasingly impeding the growth of the productive forces - namely, the multiskilling and substantive empowerment of labour.

\section{The Management Contradiction ${ }^{67}$}

On the one hand, managers increase organisational efficiency by coordinating the division and utilisation of labour. They play a productive role when engaging in coordinative labour, such as planning, work design, allocation of labour and training. On the other hand, managers also must ensure discipline within the workforce to ensure labour valorisation, that is, to secure sufficient output. Managers play an unproductive role when enforcing discipline, for instance when engaging in direct observation. In other cases, management is simultaneously coordinative and disciplinary, such as with time-and-motion study, which increases efficiency while enforcing discipline via standardisation.

The foregoing suggests that the central contradiction facing managers is between coordination (to increase efficiency) versus discipline (to ensure valorisation). It is a manifestation of the contradiction between the forces

63 Smith 1987.

64 On manufacturing, see McKay 2006; Smith 1987; Thompson 199o; Vallas 1993. On services, see Korczynski 20o9; Taylor and Bain 1999.

65 Graham 1995; Rinehart, Huxley and Robertson 1997.

66 Thompson 2003, p. 364.

67 This section expands on an argument sketched in Vidal 2019a. 
and relations of production. I submit that the management contradiction was substantially muted from the earliest stages of capitalism through the Fordist stage but has become intensified in the postfordist period.

Because capital relies on the embodied, tacit skills of labour, deskilling was always necessarily incomplete. As Friedman and Richard Edwards demonstrated, even under Taylorism, managers experienced some tensions insofar as they had to harness the tacit skills and cooperation of labour. But these tensions were subdued until the postfordist era. From the manufacture stage (sixteenth to the eighteenth centuries) through the Fordist stage (1920s through the early 1970s), the basis of efficiency was economies of scale (and automation), technologies were rigid and stable, and mass markets were still developing. Under such conditions, multiskilled and empowered workers were unnecessary, uncompetitive costs.

When the goal is to maximise output of a small number of products based on forecasts, using semiskilled workers restricted to a single task under direct or technical control is the most efficient division of labour. In this context, coordination and discipline are achieved via the same practices: direct observation, work simplification, technical control, time-and-motion study, standardisation.

A comparison between Britain, America and Germany illustrates the point that a Taylorist labour process was the most efficient approach. ${ }^{68}$ In Britain, craft control dominated in the nineteenth century and remained common through the first decades of the twentieth century. Employers contracted work to a master craftsman, who employed skilled and unskilled labour, and had an interest in passing-on craft skills. ${ }^{69}$ Further, in the struggle for control within the managerial profession, accounting remained dominant (over engineering) well into the twentieth century. These conditions combined with a powerful shop-steward movement to ensure substantial control by labour on the shopfloor and a lack of standardisation. By contrast, in the US and Germany engineering became dominant in the nineteenth century and these countries realised a higher level of process standardisation and deskilling earlier. As a result of the high degree of production control by skilled labour in Britain, the development of Fordist production in the twentieth century was hindered and delayed, allowing the US and Germany to leap ahead of Britain in industrial productivity based on Fordist production.

Over the course of the twentieth century, Fordism spread across the OECD countries. The rigid and dehumanising system of Fordist production eventually

\footnotetext{
68 Vidal 2015.
}

69 Littler 1982. 
went into crisis, experiencing widespread labour revolts in the late 196os and competition from new forms of flexible production in the 1970s. The postTaylorist model developed in Sweden by Volvo (self-directed teams) competed with the neotaylorist model developed in Japan by Toyota (employee involvement in a standard setting) and a sort of hybrid or intermediate model developed in Germany.

By the end of the 1980s, the Toyota model - lean production - emerged as the victor, becoming the universal model of best practice in postfordist manufacturing and increasingly spreading into services. ${ }^{70}$ Some critics argue that lean is a model that necessarily intensifies and deskills work. ${ }^{71}$ While lean can be a highly effective model for work intensification and can be implemented without any worker empowerment, it also can be implemented to include substantive worker participation, genuinely empowered teams and multiskilling, in some cases without intensifying work. ${ }^{72}$ Responding to advocates proposing that the lean labour process has overcome labour-management antagonism, Tony Smith demonstrated that even under lean, structural coercion and the real subsumption of labour remain. Although workers under lean may experience real increases in decision-making authority regarding issues including process control, standard setting, safety, scheduling and training, the set of issues is limited to pregiven parameters. ${ }^{73}$ Management retains the exclusive right to allocate the surplus produced, along with veto power, one-way channels of communication, and the power to withdraw participation rights unilaterally.

The key issues regarding skill and empowerment concern the focus of local management and the orientation and power of the local workforce. Further, even where managers intend to empower their workers, the pressure to maintain tight process control and get products out the door makes it difficult for them to find time to train workers and devolve responsibility. While lean can be implemented without substantive empowerment or genuine upskilling, the best-practice template of lean - which, at least in the US, is deeply institutionalised and widely understood by management - consists of demanddriven, flow production, emphasising process standardisation, economies of

70 The core lean-production model can be transferred across national institutional contexts, independently of the Japanese employment-relations institutions (Elger and Smith 1994; Liker, Fruin and Adler 1999; Oliver and Wilkinson 1992; Smith 200o).

71 Carter, Danford, Howcroft, Richardson, Smith and Taylor 2013; Parker and Slaughter 1995.

72 Adler 1993; Delbridge 2003; Jürgens 2004; Oliver and Wilkinson 1992; Rothstein 2016; Stanton, Gough, Ballardie, Bartram, Bamber and Sohal 2014; Vidal 2007b.

73 Smith 2000 . 
flexibility and continuous improvement, using multiskilled workers empowered to engage in decision-making and problem-solving. ${ }^{74}$

In the era of postfordism, the basis of efficiency became economies of scope and flexibility. In this competitive context, there is a real efficiency advantage to empowering workers, via both multiskilling and employee involvement in problem-solving and decision-making. Postfordist capitalism has thus initiated an intensification of the contradiction between coordination and discipline, which now takes the form of empowerment versus discipline.

On the management production of inefficiency, Gordon and Edwards accepted the mainstream position that humans are maximisers, positing that managers maximise control rather than efficiency. However, organisation theory and sociology have long noted that maximising utility is theoretically untenable and that in practice there is robust evidence that managers satisfice. ${ }^{75}$ Within the labour-process tradition, there have been occasional explicit references to satisficing. Both Delbridge and Elger and Chris Smith agreed that workers may be empowered under lean production, but pressure to maintain tight process control and get products out the door makes it difficult for satisficing managers to find time to train workers and devolve responsibility. ${ }^{76}$

Rather than posing two technologies in which one extracts more labour effort but is less efficient than the other, as Gordon and Edwards did, I propose competing pressures facing managers: coordinating to increase efficiency versus disciplining to ensure valorisation. The emphasis is not on outcomes (efficiency versus valorisation) but on functions (coordination versus discipline). A managerial focus on discipline can lead to an emphasis on securing physical surplus labour - a limited type of valorisation - rather than overall valorisation of physical and intellectual labour. In a satisficing model, this becomes particularly clear: under postfordism, managers may settle for the easier option of ensuring sufficient physical output, via the disciplines of direct control, technical control or standardisation, which may conflict with the most efficient organisation of the labour process, via responsible autonomy and substantive empowerment. Facing contradictory pressures for empowerment versus discipline, managers often opt for the latter at the expense of the former. I return to flesh out this argument based on my empirical research on lean in the final subsection below. But first, I discuss the workforce contradiction.

\footnotetext{
74 Vidal 2017.

75 Cyert and March 1992; March and Simon 1993; Nelson and Winter 1982; Vidal 2017; Winter 2000 .

$76 \quad$ Delbridge 2003; Elger and Smith 2005.
} 


\section{The Workforce Contradiction}

A few labour-process theorists have alluded to what I call the workforce contradiction, namely, the tension workers experience between managerial attempts to empower them, in necessarily limited ways, and their continued alienation within the capitalist labour process. Friedman suggested a contradiction between the independent will of the worker versus her subjugation and alienation within the capitalist labour process, noting that responsible autonomy is problematic when workers are alienated. ${ }^{77}$ Rinehart and colleagues noted the contradiction entailed in workers being asked to give their ideas but withdrawing their participation after seeing these ideas used to speed up their work. ${ }^{78}$ Adler discussed a contradiction between socialisation and valorisation, proposing that the productive socialisation of labour is variously 'stimulated, retarded and distorted' by valorisation pressures. ${ }^{79}$

In my interpretation, what all of these authors are circling around is a contradiction between socialisation and alienation. Friedman and Rinehart et al. specifically referred to a tension experienced by workers. Adler theorised a more general contradiction, effectively equating 'valorisation pressures' with competitive pressures, which force 'firms to develop and implement new technologies and techniques, to break down parochial market barriers' ${ }^{80}$ But for Marx, the valorisation process is 'entirely confined to the sphere of production' ${ }^{81}$ And the valorisation imperative is a pressure affecting managers. In contrast, socialisation, like alienation, is a process affecting workers: 'The social productive forces of labour, or the productive forces of directly social, socialised (i.e. collective) labour, are developed through cooperation, division of labour within the workshop, the use of machinery.' Socialisation is the process by which the development of the forces of production occurs through the social development of labour.

The foregoing suggests a workforce contradiction, which consists of the tension workers experience between productive socialisation (the upgrading of productive capability) and alienation. Again, this contradiction is a manifestation of the contradiction between the forces and relations of production, and was also muted in the earliest phases of capitalism. In postfordism it is increasingly experienced by workers as a tension over whether to embrace

$77 \quad$ Friedman 1977 .

78 Rinehart, Huxley and Robertson 1997.

79 Adler 2007, p. 1324.

8o Adler 2007, pp. 621, 1324.

81 Marx 1990, pp. 302, 1024; emphasis in original. 
empowerment - increasingly necessary for efficient production - in a context of continued alienation.

On alienation, I agree with Willmott that Marx's theory of human nature has a romantic aspect insofar as it is based on an ahistorical essence which sees the possibility for self-realisation as existing solely within a production process where human labour is fully autonomous and produces a complete product. ${ }^{82}$ Willmott theorised alienation by emphasising the individualising nature of capitalism, with the effects of capitalist competition and individualist ideology stoking ontological anxieties. Such anxieties can lead to a 'fetishised form of self-consciousness' in which workers embrace particular identities, often in ways that lead to conservative, individualist positions rather than progressive, collectivist positions.

Most importantly for present purposes, Willmott suggested that the desire for a secure identity and a reduction of anxiety may lead workers to cling to existing routines, even if these deskilled routines are 'seemingly devoid of "self-expression". ${ }^{33}$ This analysis helps make sense of findings that workers are often reluctant or resistant to taking on more problem-solving and decisionmaking responsibility. Even if workers are offered some genuine increases in their skills and decision-making authority, they understand that they will be asked to take on increasingly managerial responsibilities without any commensurate increase in managerial rights. Indeed, their empowerment will be limited to concerns with process or product improvement, while traditional management will continue to be the ultimate authority, ready to exercise a veto or remove (partial) worker empowerment at any time. The contradiction between (partial) empowerment and (continued) alienation drives scepticism, reticence and resistance toward the former.

\section{The Systematic Production of Inefficiency by Capitalist Management} The management contradiction is experienced by managers as conflicting pressures regarding whether to empower or discipline labour. The workforce contradiction is experienced by workers as a tension regarding whether they should embrace partial empowerment while remaining within an alienating labour process.

These contradictions reinforce each other. Even if any particular management is able to surmount the management contradiction and attempt to empower its workers, managers often find their requests for workers to contribute

$82 \quad$ Willmott 1990, p. 371.

83 Willmott 1990, p. 363 . 
to problem-solving and decision-making met with resistance or reticence. ${ }^{84}$ While some workers may not want increased responsibilities, considering worker alienation helps make sense of widespread resistance or reticence of workers in respect of their own empowerment.

In the remainder of this section, I focus on manufacturing as the main site of my empirical research on employee involvement and draw freely from these studies. ${ }^{85}$ But first, to provide a rough estimate of what percentage of occupations would potentially realise increased productivity, flexibility or continuous improvement via substantive worker empowerment but are subject to contradictory pressures, I draw on a typology classifying the US occupational structure into four generic types of labour process based on physical technologies, task environments and authority relations. ${ }^{86}$

High-skill autonomous occupations (e.g. managers and professionals) typically require university and often postgraduate education and constitute around $38 \%$ of the workforce. Semiautonomous occupations (e.g. supervisors, secretaries, technicians, high-end receptionists) are semi- or high-skill jobs typically requiring extensive job-specific, vocational and/or university training, constituting around $27 \%$ of the workforce. Tightly constrained occupations (e.g. retail clerks and cashiers, assemblers and machine operators, phone operators, bank tellers) are semi-skilled jobs requiring job-specific or limited vocational training, constituting around $7 \%$ of the workforce; work is paced by machine technology, job standards or customer-service scripts. Unrationalised labour-intensive occupations (e.g. bartenders, waitstaff, cooks, health aids, dental assistants, hairdressers, janitors, truck drivers, low-end receptionists) are low-skill jobs requiring limited on-the-job training, constituting around $28 \%$ of the workforce; this work is not susceptible to machine pacing, standardisation or scripting.

The high-skill autonomous occupations (roughly $38 \%$ of the total workforce) consist of high-level managers and professionals. This category comprises the salariat: salaried workers with high incomes and dense organic ties with the capitalist class proper (owners of the means of production), including authority over wage workers, involvement in organisational policy-making, and a deep financial stake in the capitalist system. The remaining $62 \%$ of the workforce consists of wage workers, what might be called the extended working class. Although even much of the salariat is also subject to standardisation

\footnotetext{
84 Delbridge 2003; Elger and Smith 2005; Friedman 1977; Rinehart, Huxley and Robertson 1997; Vidal 2007a; Vidal 2007b; Vidal 2017.

85 Vidal 2007a; Vidal 2007b; Vidal 2009; Vidal 2017.

86 Vidal 2013a.
} 
pressures and threats to their professional autonomy, they are not under direct managerial supervision in the same way as the working class.

For those under direct managerial authority, substantive empowerment would provide a productivity/flexibility benefit wherever work consists of a process flow involving multiple steps that are open to refinement, likely to change based on technical improvements, or inherently uncertain due to the nature of the process. This includes most semi-autonomous occupations (roughly $27 \%$ of the total wage and salary workforce or $44 \%$ of the extended working class), which typically provide a limited degree of decision-making authority but are also subject to strong standardisation pressures. It also includes around half of tightly-constrained occupations (assemblers and machine operators, phone operators, bank tellers $-4 \%$ of the total workforce or $6 \%$ of the working class), but not retail clerks and cashiers, which are very simple task environments with stable technologies. And it includes perhaps half of unrationalised labour-intensive occupations, mainly administrative support (e.g. receptionists) and some service occupations (e.g. health aids) ( $14 \%$ of the total workforce or $23 \%$ of the working class) but not occupations like bartenders, cooks and janitors, which involve simple work with limited opportunity for increased productivity via empowerment. This suggests, roughly, that $45 \%$ of the total workforce - and $73 \%$ of the working class - are in occupations where management experiences intense pressure to ensure discipline via standardisation and deskilling but where substantive empowerment would increase productivity/flexibility.

There is robust evidence that substantive employee involvement has a statistically significant effect on performance and that the effect is strongest when combined with a comprehensive package of complementary practices. ${ }^{87}$ And, within American manufacturing at least, there is broad agreement among managers that lean production with worker empowerment constitutes best practice. 88

In the postfordist era, capitalist management is producing inefficiency insofar as it fails to empower workers to engage in intellectual labour (problemsolving and decision-making) or to train them in multiple skills. The most competitive and innovative firms are those that substantively empower their workers. The failure to empower workers is an outcome of managers satisficing in response to both the management and the workforce contradictions.

87 Appelbaum, Bailey, Berg and Kalleberg 2000; Cotton 1993; Levine and Tyson 1990; MacDuffie 1995 .

88 Vidal 2017. 
Genuinely empowering workers to take on responsibilities that were formerly the province of management, to enthusiastically expend discretionary effort to engage in problem-solving and decision-making, is exceptionally difficult. On the management contradiction, managers face severe pressures to keep machines running, maximise uptime, and to get products out the door. In the everyday operation of a typical factory, managers face multiple competing demands on their time, from key industrial customers, key suppliers and senior corporate managers, from various departments within their own organisation, and from their own set of strategic concerns (products, technologies, skillsets, core competencies, supplier management, strengths, weaknesses, threats, opportunities, etc.). A typical factory manager spends most of her time fighting fires, on the defensive, preoccupied with getting often-late parts out the door.

In such a context, the emphasis of factory management is generally on ensuring physical output to meet customer demands. Managers necessarily must satisfice. This means setting priorities and choosing some goals over others, and although managers may intend to return to deprioritised goals at a later date, since the pressures are continuous, goals often become permanently demoted. They focus on short-term rather than long-term goals, on immediate output rather than training and empowering workers for increased flexibility and continuous improvement. In many cases such incessant pressure means adjusting aspiration levels downward to maintain focus and reduce stress.

So long as key customers are being satisfied, there is not intense pressure to empower workers, even if doing so would increase productivity and flexibility. ${ }^{89}$ Facing the sheer complexity of implementing world-class practice, managers may settle for arrangements that ensure sufficient levels of surplus labour but don't maximise productivity, flexibility or continuous improvement capability. My own research finds managers meeting customer targets using inefficient methods such as intensive sorting (for quality), prebuilding stocks (for delivery), and even sacrificing their own margins (for price) rather than doing so via lean methods using empowered workers. Other research on British and American automobile assembly shows management often choosing work intensification and uptime over substantive empowerment to drive continuous improvement. ${ }^{90}$

Individual managers vary in their aspiration levels. Although these may be adjusted up or down as a way of adjusting expectations, in general they are relatively stable. This explains why there is such variation in the extent to which workers are empowered in any particular workplace: only managers

\footnotetext{
89 Vidal 2007b; Vidal 2017.

90 Rothstein 2016; Stewart, Richardson, Danford, Murphy, Richardson and Wass 2009.
} 
with the highest aspiration levels (and highest competence levels) work to overcome these competing pressures by finding integrative solutions to competing goals. ${ }^{91}$ Some managers put extensive effort into substantively empowering their workers, while others are content with consultative participation and some cross-training to facilitate job rotation among simple tasks.

However, even where a manager has a sufficiently high aspiration level to maintain substantive worker empowerment as a high priority, she may face an additional difficulty stemming from the workforce contradiction: resistance or reticence from these workers. Managers cannot simply tell workers they are empowered and expect that to become institutionalised. Humans are creatures of habit and are resistant to change; workers and managers slip back into old routines. In general, it takes a high level of dedication to ensure that new changes become institutionalised within any organisation. With regard to alienated workers, the challenge is even more difficult because existing routines provide a source of security and even identity.

Some workers do not like the variety that academics fetishise. As one worker I interviewed explained in response to a new system of cross-training, 'I had a routine ... I like running the same machine. I mean, just walking into the job and start running. Where you, some of the other jobs, if you're not used to running them, you've got to figure out the ins and outs in a lot of them.92 As another worker stated, 'I'd like to know exactly where I'm going to be from one day to the next.' And workers actively create meaningful work even in a traditional Taylorist context: 'I like challenging myself to see if I can make the rate or how fast I can go. ${ }^{93}$

In response to demands to engage in problem-solving and decision-making, one worker responded bluntly: 'I don't want a higher-level job where I'd have stress that I would have to take home. For me it's, what's outside of work, you know.' Experiencing increased responsibility as stressful was common in my research. Another worker stated, regarding job rotation and devolved responsibilities: 'It's a jungle, I don't like it.'94

These brief examples illustrate how workers are often relatively satisfied with and attached to Taylorist routines and can be resistant to both job rotation and taking on more responsibility. While the latter may arise out of a principled, strategic refusal to cooperate or expend discretionary effort, my interviews with workers suggest that a fundamental source of such resistance and

91 Vidal 2007b; Vidal 2017.

92 Vidal 2007a.

93 See also Burawoy 1982; Rinehart, Huxley and Robertson 1997, p. 337.

94 Vidal 2007a. 
reticence is alienation and awareness that such empowerment will necessarily be partial, that management can veto their ideas or revoke their empowerment at any time. Their alienation within a capitalist labour process reinforces a more general human tendency to adhere to existing routines. And their experience tells them that their empowerment will be systematically limited, often to simply providing input without any authority, but even where they are given some decision-making authority it will be limited to decisions over process and product-design that are ultimately subject to the specific priorities of management and managerial veto. ${ }^{95}$ They may gain some increased control over the production process but will still have no control over investment decisions, training decisions, etc. Such reluctance to participate in managerial initiatives is reinforced by experience with management fads of the month and/or work intensification.

In sum, managers may settle for control strategies that secure sufficient physical effort from workers but do not fully tap worker creativity and discretionary effort, because securing the latter requires changes that are exceedingly difficult to implement and sustain. Even where managers attempt to pursue empowerment they are likely to be confronted with the difficulties of getting alienated workers to contribute discretionary effort and intellectual labour.

Such managerial satisficing is generally less about managers protecting their power or control as such and more about settling for 'good enough' when facing the difficulties of empowering labour. But to the extent that empowerment is systematically limited to decisions over process and product-design, senior managers are also protecting their power and the control of capitalists over the production process.

If satisficing in response to the management and workforce contradictions is a systematic feature of the postfordist labour process, capitalist management is retarding technical growth. The evidence of management in individual workplaces failing to substantively empower their workers is compelling enough to warrant the development of a research programme examining the production of inefficiency by capitalist management. While Marxist work on this question has been suggestive, it has not been systematic or sustained. Likewise, labour-process scholars have ritually referred to the role of contradictions but have not made these a core analytical focus.

A research programme examining the management and workforce contradictions could reinvigorate labour-process theory, help it to explain variation in workplace outcomes, and provide a basis for a political critique of capitalist

95 Vidal 2007b; Graham 1995, p. 316; Rinehart, Huxley and Robertson 1997, p. 337; Rothstein 2016, p. 1407 . 
management that moves beyond deskilling and intensification. Capitalists have used efficiency as a blanket rationale for every move they make, including disinvestment, downsizing, work intensification and so on. It is time that Marxist labour-process theory, following the pioneering work of Gorz and Mallet, Gordon and Edwards, and Noble, incorporates the capitalist production of inefficiency into the critique of capitalism.

\section{Acknowledgments}

I would like to thank Paul Adler and Chris Nyland for written comments and extensive discussions over many of the ideas in this paper, Tony Smith for written comments, and Zlatko Bodrozic and Ian Greer for help with the concept of Vergesellschaftung (socialisation). My analysis has also been influenced by ongoing conversations with Chris Smith, Paul Thompson, and Steve Vallas.

\section{References}

Adler, Paul S. 199o, 'Marx, Machines, and Skill', Technology and Culture, 31: 780-812.

Adler, Paul 1993, "The Learning Bureaucracy: New United Motor Manufacturing Inc.', in Research in Organizational Behavior, edited by Barry M. Staw and Larry L. Cummings, Greenwich, CT: JAI.

Adler, Paul S. 2007, 'The Future of Critical Management Studies: A Paleo-Marxist Critique of Labour Process Theory', Organization Studies, 28: 1313-45.

Aglietta, Michel 2000 [1976], A Theory of Capitalist Regulation: The U.S. Experience, London: Verso.

Albizu, Eneka and Mikel Olazaran 2006, 'BPR Implementation in Europe: The Adaptation of a Management Concept', New Technology, Work \& Employment, 21: 43-58.

Albritton, Robert, Makoto Itoh, Richard Westra and Alan Zuega 2001, Phases of Capitalist Development: Booms, Crises and Globalization, Basingstoke: Palgrave.

Amin, Ash 1994, Post-Fordism: A Reader, Oxford: Blackwell.

Appelbaum, Eileen, Thomas Bailey, Peter Berg and Arne Kalleberg 20oo, Manufacturing Advantage, Ithaca, NY: Cornell University Press.

Belfrage, Claes 2017, 'The Unintended Consequences of Financialisation: Social Democracy Hamstrung? The Pensions Dilemma,' Economic and Industrial Democracy, 38: 701-22.

Boyer, Robert 1997, 'How Does a New Production System Emerge?', in After Fordism, edited by Robert Boyer and Jean-Pierre Durand, Basingstoke: Palgrave Macmillan. 
Boyer, Robert and Yves Saillard 2002, Régulation Theory: The State of the Art, London: Routledge.

Braverman, Harry 1974, Labor and Monopoly Capital: The Degradation of Work in the Twentieth Century, New York: Monthly Review Press.

Brenner, Robert and Mark Glick 1991, 'The Regulation Approach: Theory and History', New Left Review, I, 188: 45-119.

Burawoy, Michael 1982, Manufacturing Consent: Changes in the Labor Process under Monopoly Capitalism, Chicago: University of Chicago Press.

Callinicos, Alex 20o9, Making History: Agency, Structure, and Change in Social Theory, Historical Materialism Book Series, Chicago: Haymarket Books.

Carter, Bob, Andy Danford, Debra Howcroft, Helen Richardson, Andrew Smith and Phil Taylor 2013, "'Stressed Out Of My Box": Employee Experience of Lean Working and Occupational Ill-health in Clerical Work in the UK Public Sector', Work, Employment \& Society, 27, 5: 747-67.

Clarke, Simon 1992, 'What in the F---'s Name is Fordism', in Fordism and Flexibility: Divisions and Change, edited by Nigel Gilbert, Roger Burrows and Anna Pollert, Basingstoke: Palgrave Macmillan.

Cotton, John L. 1993, Employee Involvement: Methods for Improving Performance and Work Attitudes, London: SAG E Publications.

Cressey, Peter and John MacInnes 1980, 'Voting for Ford: Industrial Democracy and the Control of Labour', Capital \& Class, 4: 5-33.

Crowley, Martha, Daniel Tope, Lindsey Joyce Chamberlain and Randy Hodson 2010, 'Neo-Taylorism at Work: Occupational Change in the Post-Fordist Era', Social Problems, 57: 421-47.

Cyert, Richard M. and James G. March 1992 [1963], A Behavioral Theory of the Firm, Cambridge, MA: Blackwell.

Danford, Andy 1999, Japanese Management Techniques and British Workers, London: Mansell.

Delbridge, Rick 2003, Life on the Line in Contemporary Manufacturing: The Workplace Experience of Lean Production and the 'Japanese' Model, Oxford: Oxford University Press.

Edwards, Richard 1979, Contested Terrain: The Transformation of the Workplace in the Twentieth Century, London: Heinemann.

Elger, Tony 1979, 'Valorisation and “Deskilling”: A Critique of Braverman', Capital \& Class, 3: 58-99.

Elger, Tony and Chris Smith 1994, GlobalJapanization: The Transnational Transformation of the Labour Process, London: Routledge.

Elger, Tony and Chris Smith 2005, Assembling Work: Remaking Factory Regimes in Japanese Multinationals in Britain, Oxford: Oxford University Press.

Engels, Frederick 1978 [1874], 'On Authority', in Tucker (ed.) 1978. 
Friedman, Andrew L. 1977, Industry and Labour: Class Struggle at Work and Monopoly Capitalism, London: Macmillan.

Gordon, David M. 1976, 'Capitalist Efficiency and Socialist Efficiency', Monthly Review, 28: 19-39.

Gordon, David M., Richard Edwards and Michael Reich 1982, Segmented Work, Divided Workers: The Historical Transformation of Labor in the United States, Cambridge: Cambridge University Press.

Gorz, André 1968, Strategy for Labor: A Radical Proposal, translated by Martin A. Nicolaus and Victoria Ortiz, Boston, MA: Beacon Press.

Gorz, André 1976, 'Technology, Technicians and Class Struggle', in The Division of Labour: The Labour Process and Class Struggle in Modern Capitalism, edited by André Gorz, Brighton: The Harvester Press.

Graham, Laurie 1995, On the Line at Subaru-Isuzu:The Japanese Model and the American Worker, Ithaca, NY: Cornell University Press.

Jessop, Bob 1992, 'Fordism and Post-Fordism: A Critical Reformulation', in Pathways to Industrialization and Regional Development, edited by Michael Storper and Alan J. Scott, London: Routledge.

Jessop, Bob 1997, 'Twenty Years of the (Parisian) Regulation Approach: The Paradox of Success and Failure at Home and Abroad', New Political Economy, 2: 503-26.

Jessop, Bob 2002, The Future of the Capitalist State, Cambridge: Polity Press.

Jessop, Bob 2012, 'The World Market, Variegated Capitalism and the Crisis of European Integration', in Globalisation and European Integration, edited by Petros Nousios, Henk Overbeek and Andreas Tsolakis, London: Routledge.

Jessop, Bob 2014, 'Variegated Capitalism, das Modell Deutschland, and the Eurozone Crisis', Journal of Contemporary European Studies, 22: 248-6o.

Jürgens, Ulrich 2004, 'An Elusive Model - Diversified Quality Production and the Transformation of the German Automobile Industry', Competition \& Change, 8: $411-23$.

Korczynski, Marek 20o9, 'Understanding the Contradictory Lived Experience of Service Work: The Customer-oriented Bureaucracy', in Service Work: Critical Perspectives, edited by Marek Korczynski and Cameron Lynne Macdonald, London: Routledge.

Landes, David S. 1986, 'What Do Bosses Really Do?', The Journal of Economic History, 46: $5^{8} 5^{-623 .}$

Leverment, Yvonne, Peter Ackers and Diane Preston 1998, 'Professionals in the NHS A Case Study of Business Process Re-engineering, New Technology, Work and Employment, 13: 129-39.

Levine, David I. and Laura D’Andrea Tyson 1990, 'Participation, Productivity, and the Firm's Environment', in Paying for Productivity: A Look at the Evidence, edited by Alan S. Blinder, Washington, D.C.: Brookings Institution. 
Liker, Jeffrey K., W. Mark Fruin and Paul S. Adler 1999, Remade in America:Transplanting and Transforming Japanese Management Systems, Oxford: Oxford University Press.

Lipietz, Alain 1986, 'Behind the Crisis: The Exhaustion of a Regime of Accumulation. A "Regulation School" Perspective on some French Empirical Works', Review of Radical Political Economics, 12: 13-32.

Lipietz, Alain 1992, Towards a New Economic Order:Postfordism, Ecology and Democracy, translated by Malcolm Slater, Cambridge: Polity Press.

Littler, Craig R. 1982, The Development of the Labour Process in Capitalist Societies, London: Heinemann.

Lowe, James, Rick Delbridge and Nick Oliver 1997, 'High-Performance Manufacturing: Evidence from the Automotive Components Industry', Organization Studies, 18: 783-98.

MacDuffie, John Paul 1995, 'Human Resource Bundles and Manufacturing Performance: Organizational Logic and Flexible Production Systems in the World Auto Industry', Industrial and Labor Relations Review, 48: 197-221.

Mallet, Serge 1975, The New Working Class, translated by Andrée Shepherd and Bob Shepherd, Nottingham: Spokesman Books.

Mandel, Ernest 199o [1976], 'Introduction', in Marx 1990.

March, James G. and Herbert A. Simon 1993 [1958], Organizations, Second Edition, Oxford: Blackwell.

Marglin, Stephen A. 1974, 'What Do Bosses Do?:The Origins and Functions of Hierarchy in Capitalist Production', Review of Radical Political Economics, 6: 6o-112.

Marglin, Stephen A. and Juliet B. Schor 2007, The Golden Age of Capitalism: Reinterpreting the Postwar Experience, Oxford: Clarendon Press.

Marx, Karl 1978a [1844], 'Economic and Philosophic Manuscripts of 1844', in Tucker (ed.) 1978.

Marx, Karl 1978b [1859], 'Preface to A Contribution to the Critique of Political Economy', in Tucker (ed.) 1978.

Marx, Karl 1981 [1894], Capital: A Critique of Political Economy. Volume Three, translated by David Fernbach, Harmondsworth: Penguin.

Marx, Karl 199o [1867], Capital: A Critique of Political Economy. Volume One, translated by Ben Fowkes, Harmondsworth: Penguin.

Marx, Karl 1993 [1857-8], Grundrisse: Foundations of the Critique of Political Economy, translated by Martin Nicolaus, Harmondsworth: Penguin.

Marx, Karl and Friedrich Engels 1978 [1848], 'Manifesto of the Communist Party', in Tucker (ed.) 1978.

McKay, Steven C. 2006, Satanic Mills or Silicon Islands? The Politics of High-Tech Production in the Philippines, Ithaca, NY: ILR Press.

Nelson, Richard R. and Sidney G. Winter 1982, An Evolutionary Theory of Economic Change, Cambridge, MA: Harvard University Press. 
Noble, David F. 1986, Forces of Production: A Social History of Industrial Automation, Oxford: Oxford University Press.

Oliver, Nick and Barry Wilkinson 1992, The Japanization of British Industry: New Developments in the 199os, Oxford: Blackwell.

Palloix, Christian 1976, 'The Labour Process: From Fordism to neo-Fordism', in The Labour Process \& Class Struggle, edited by Conference of Socialist Economists, London: stage 1.

Parker, Mike and Jane Slaughter 1995, 'Unions and Management by Stress', in Lean Work: Empowerment and Exploitation in the Global Auto Industry, edited by Steve Babson, Detroit: Wayne State University Press.

Peck, Jamie and Nik Theodore 2007, 'Variegated Capitalism', Progress in Human Geography, 31: 731-72.

Piore, Michael J. and Charles F. Sabel 1984, The Second Industrial Divide: Possibilities for Prosperity, New York: Basic Books.

Rinehart, James, Christopher Huxley and David Robertson 1997, Just Another Car Factory? Lean Production and Its Discontents, Ithaca, NY: Cornell University Press.

Rothstein, Jeffrey S. 2016, When Good Jobs Go Bad: Globalization, De-Unionization, and Declining Job Quality in the North American Auto Industry, New Brunswick, NJ: Rutgers University Press.

Ryner, J. Magnus and Alan W. Cafruny 2017, The European Union and Global Capitalism: Origins, Development, Crisis, Basingstoke: Palgrave.

Smith, Chris 1987, Technical Workers: Class, Labour and Trade Unionism, Basingstoke: Macmillan Education.

Smith, Chris 2015, 'Continuity and Change in Labor Process Analysis Forty Years after Labor and Monopoly Capital', Labor Studies Journal, 40: 222-42.

Smith, Tony 200o, Technology and Capital in the Age of Lean Production, Albany, NY: sUNY Press.

Stanton, Pauline, Richard Gough, Ruth Ballardie, Timothy Bartram, Greg J. Bamber and Amrik Sohal 2014, 'Implementing Lean Management/Six Sigma in Hospitals: Beyond Empowerment or Work Intensification?', The International Journal of Human Resource Management, 25: 2926-40.

Stewart, Paul, Mike Richardson, Andy Danford, Ken Murphy, Tony Richardson and Vicki Wass 2009, We Sell Our Time No More: Workers' Struggles against Lean Production in the British Car Industry, London: Pluto Press.

Taylor, Phil and Peter Bain 1999, "An Assembly Line in the Head”: Work and Employee Relations in the Call Centre', Industrial Relations Journal, 30: 101-17.

Thomas, Robert J. 1994, What Machines Can't Do:Politics and Technology in the Industrial Enterprise, Berkeley: University of California Press.

Thompson, Paul 1983, The Nature of Work: An Introduction to Debates on the Labour Process, London: Macmillan. 
Thompson, Paul 1990, 'Crawling from the Wreckage: The Labour Process and the Politics of Production', in Labour Process Theory, edited by David Knights and Hugh Willmott, London: Macmillan.

Thompson, Paul 2003, 'Disconnected Capitalism: Or Why Employers Can't Keep Their Side of the Bargain', Work, Employment \& Society, 17: 359-78.

Thompson, Paul and Chris Smith 2009, 'Labour Power and Labour Process: Contesting the Marginality of the Sociology of Work', Sociology, 43: 913-30.

Thompson, Paul and Diane van den Broek 2010, 'Managerial Control and Workplace Regimes: An Introduction', Work, Employment \& Society, 24: 1-12.

Tucker, Robert C. (ed.) 1978, The Marx-Engels Reader, New York: W.W. Norton and Company.

Vallas, Steven Peter 1993, Power in the Workplace: The Politics of Production at AT\&T, Albany, NY: sunY Press.

Vidal, Matt 2007a, 'Lean Production, Worker Empowerment, and Job Satisfaction: A Qualitative Analysis and Critique', Critical Sociology, 33: 247-78.

Vidal, Matt 2007b, 'Manufacturing Empowerment? "Employee Involvement" in the Labour Process after Fordism', Socio-Economic Review, 5: 197-232.

Vidal, Matt 2009, 'Routine Inefficiency: Operational Satisficing in Real-World Markets', in Economic Sociology of Work: Research in the Sociology of Work, Volume 18, edited by Nina Bandelj, Bingley: Jai Press.

Vidal, Matt 2012, 'On the Persistence of Labor Market Insecurity and Slow Growth in the US: Reckoning with the Waltonist Growth Regime', New Political Economy, 17: 543-64.

Vidal, Matt 2013a, 'Low-autonomy Work and Bad Jobs in Postfordist Capitalism', Human Relations, 66: 587-612.

Vidal, Matt 2013b, 'Postfordism as a Dysfunctional Accumulation Regime: A Comparative Analysis of the USA, the UK and Germany', Work, Employment \& Society, 27: 451-71.

Vidal, Matt 2014, 'Incoherence and Dysfunctionality in the Institutional Regulation of Capitalism', in Comparative Political Economy of Work, edited by Marco Hauptmeier and Matt Vidal, Basingstoke: Palgrave Macmillan.

Vidal, Matt 2015, 'Fordism and the Golden Age of Atlantic Capitalism', in The SAGE Handbook of the Sociology of Work and Employment, edited by Stephen Edgell, Heidi Gottfried and Edward Granter, London: SAGE Publications.

Vidal, Matt 2017, 'Lean Enough: Institutional Logics of Best Practice and Managerial Satisficing in American Manufacturing', Socius, 3: 1-17.

Vidal, Matt 2019a, 'Work and Exploitation in Capitalism: The Labor Process and the Valorization Process', in Vidal, Smith, Rotta and Prew (eds.) 2019.

Vidal, Matt 2019b, 'Geriatric Capitalism: Stagnation and Crisis in Western Capitalism', in Vidal, Smith, Rotta and Prew (eds.) 2019. 
Vidal, Matt and Marco Hauptmeier 2014, 'Comparative Political Economy and Labour Process Theory: Toward a Synthesis', in Comparative Political Economy of Work, edited by Marco Hauptmeier and Matt Vidal, Basingstoke: Palgrave Macmillan.

Vidal, Matt, Tony Smith, Tomás Rotta and Paul Prew (eds.) 2019, The Oxford Handbook of Karl Marx, New York: Oxford University Press.

Williams, Karel, Colin Haslam and John Williams 1992, 'Ford versus Fordism: The Beginning of Mass Production?', Work, Employment and Society, 6: 517-55.

Willmott, Hugh 199o, 'Subjectivity and the Dialectics of Praxis: Opening up the Core of Labour Process Analysis', in Labour Process Theory, edited by David Knights and Hugh Willmott, London: Macmillan.

Winter, Sidney G. 2000, 'The Satisficing Principle in Capability Learning', Strategic Management Journal, 21: 981-96. 